\title{
NATIONAL HEALTH COVERAGE SYSTEM : PHARMACISTS AND JKN PARTICIPANT SATISFACTION IN PRIMARY HEALTH FACILITIES
}

\author{
Satibi ${ }^{1}$, Diah Ayu P. ${ }^{2}$, Putu Dyana C. ${ }^{1}$, Sendy Stefanie L. ${ }^{1}$, Nike Puliansari ${ }^{1}$
}

1Faculty of Pharmacy

Universitas Gadjah Mada Skip

Utara 55281

${ }^{2}$ Faculty of Medicine

Universitas Gadjah Mada,

Skip Utara 55281

Submitted: $13-12-2015$

Revised: 25-02-2016

Accepted: 15-03-2016

*Corresponding author Satibi

Email:

wali@ksu.edu.sa

\begin{abstract}
National Health Insurance (JKN) is a health protection system for participants to obtain health care benefits and protection to meet basic health needs that organized based on social insurance and equity principles. JKN, in cooperation with the primary health facilities provides comprehensive health services including pharmacy services. Pharmacist responsible for drug availability and affordability that affected by drug procurement process, drug distribution process, and drug cost claiming process. This research aimed to determine relationship between National Health Insurances services to pharmacists satisfaction and to determine relationship between pharmacy services to outpatient satisfaction at primary health facilities. Data used in research are primary data that collected through questionnare and interview. The method used was purposive sampling which the data was analyzed using linear and multiple regresions and significant value $(p)$. The number of respondents was 40 pharmacists and 150 patients in health centers and primary clinics scattered in Sleman, Bantul, and Kota Yogyakarta. The results showed that the process of procurement $(p=0.010)$ and distribution of drugs $(p=0.002)$ had a relationship with a pharmacist satisfaction except process of drug claims $(p=0.261$. Related to the satisfaction of the outpatient pharmacy services result there was a relationship of drug availability $(p=0.003)$, service time $(p=0.006)$, and drug information $(p=0.000)$ to the satisfaction of outpatients. The conclusion of this study was the process of procurement and distribution of drugs had a relationship with pharmacist satisfaction. In addition, the availability of pharmacy services such as medication, a drug services, and the provision of drug information also has a significant relationship to the satisfaction of outpatients in primary health facilities.
\end{abstract}

Keywords: pharmacy services, pharmacists, patients, JKN

\section{INTRODUCTION}

The National Health Insurance is a health protection system for all the citizen of Indonesia governed by BPJS Kesehatan (Departemen Kesehatan, 2011) in collaboration with the Primary Health Facilities and Advanced Level Referral Health Facilities. Government apply the concept where FKTP (primary health care and primary clinic) as a gate keeper which take the responsibility of primary health care as well as to function optimally according to the standard of competence include pharmacy services.
This study focused on pharmacy services, a form of service and direct responsibility of the pharmacist profession to improve the patients quality of life. On National Health Insurance system, pharmacists face the challenge of affordability and accessibility of drugs, including the availability and equitable distribution of the drug. Affordability of drugs obtained through the pricing of drugs in the e-catalog, while the accessibility of drugs related to the provision of funds, procurement and distribution of drugs (Muliawan, 2013). 
Success in pharmacy services can be seen from patient satisfaction with the receiving pharmaceutical services (Pohan, 2007). Patient satisfaction will indicate the availability and accessibility of drugs that can also demonstrate a successful of the National Health Insurance system. Pharmacist satisfaction in the pharmacy services is also an important process known as employees with high job satisfaction will be concerned with the quality of his work, tied to the organization, more productive, longer enduring work, and tried to give the best. Job satisfaction is most affected by the workload (Buciuniene et al., 2005) and have an impact on a person's performance (Aziri, 2011).

Based on the background described above, this research was done to see the pharmacist and patient satisfactions in National Health Insurance system in pharmacy services. The study was conducted in Primary Health Facilities, namely health centers and primary clinics in Sleman, Bantul and City of Yogyakarta. The results, hopefully, could be used as an evaluation for BPJS and pharmacists as pharmacy service providers, so that capable of continuously improving the quality of health care for all National Health Insurance participants.

\section{MATERIAL AND METHODS Study design}

The study was conducted with a crosssectional survey design using purposive sampling method. The respondents were pharmacists $(n=40)$ and outpatients $(n=150)$ who meet predetermined criteria. Predetermined inclusion criteria.

\section{Outpatient questionnaires as follows}

The patients were those more than 18 old outpatient at Primary Health Facilities (health centers and primary clinics) in Sleman, Bantul, and City of Yogyakarta. Patients were participants of the National Health Insurance. Patients were willing to participate in this study by completing a questionnaire. The patient was cooperative and capable to well communicate. The patient have been visited the health services at least twice since the National Health Insurance system took in effect.

\section{Pharmacist questionnaires as follows}

Pharmacists who work in health centers and primary clinics located in Sleman, Bantul and City of Yogyakarta, and are listed as FKTP collaboration with BPJS. Pharmacists are willing to participate in this study by completing a questionnaire and conduct interviews. Pharmacists are not currently in studies or are in the period of leave.

\section{Research instruments}

The research instrument used was a questionnaire with assessment using a 4-point Likert scale. Statement in the questionnaire was made with reference to the legislation applicable and practical guidance related to national health insurance system published by BPJS.

Since a questionnaire was used in this study, the questions have to be tested for its validity and reliability. The tests conducted on 30 respondents. Validity was evaluated by Pearson correlation method (valid if sig> $0.361)$. There were three invalid questions in the questionnaire for pharmacists i.e, no. 8, 10, and 14 while 9 items invalid questions for outpatients, namely no. 3, 4, 10, 19, 22, 23, 27, 28 , and 32 . All variables indicated reliable by Cronbach's alpha values $>$ 0.6. The invalid questions for pharmacists related to the payment claims because the health centers have not made a claim to BPJS yet. Meanwhile, these health centers has used capitation funds and has not carried out the reconciliation program yet which patients should be given medication for 30 days (I) (Table I).

\section{Data analysis}

Data processing was performed using multiple analysis include descriptive statistical analysis, the classical assumption test, chi square analysis, and linear regression analysis, which calculated using computerized statistics.

\section{RESULTS AND DISCUSSION Descriptive analysis of patient charac- teristics}

Characteristic of respondents were mostly in the age range of 33 to 47 years (34.67\%) which wasproductive age. The patient as well as with the elderly will be more likely to use health facilities services. Although the elderly patients 
have spesial day for examination. The majority of respondents has an income of $<1$ million $(61.33 \%)$. These patients tendaed to choose more adequate health services, despite having to incur additional costs, thereby reducing the interest of the patient to visit the clinic. In contrast to patients who have a low income, would prefer choose health services that have been determined by the government since this won't be to incur additional costs.

\section{Relationship analysis of patient charac- teristics with patient satisfaction against pharma ceutical services}

Data from the analyzed variables were determined as categorical data. The test was analyzed using Chi Square test with $\mathrm{p}<0.05$ means that there was a significant difference or there was a relationship between independent variables and the dependent variable (Dahlan, 2011).

The older a patient is getting more demanding to choose the health center, seeked higher standart servics and were more familiar with attendant of the health centers (Tabel III) (Ratnasari, 2012). Patients who have a large income were more demanding higher standard services. In contrast to patients who have low incomes, tend to be more accepting to the service provided. In the health care, someone who pay services will tend to be more demanding with more appropriate services (not easily satisfied) compared to that of someone who does not pay or pay less. How ever, this is not independent of other factors that influence.

The results showed that occupation, education, and membership status have no relationship with patient satisfaction. This is in contrast to some previous studies. This type of work can affect patient satisfaction with the services organized by the health facility, for example, those whom government officials / civil / military officials of high rank, sometimes think that doctors and nurses as their staff so that they demand higher standard of services provided by doctors and nurses (Notoatmodjo, 2010). Patients with the occupation categories as workers will tend to be passive and afraid to inquire about the treatment of the disease. Green theory (Anjaryani, 2009) indicates that knowledge influence the attitudes and behavior of people that will have an effect in more rational response to the information that is coming and will think the extent to which benefits may be derived from the idea.

Simple linear regression analysis is used to examine the relationship between the independent variable on the dependent variable (have a relationship if the $\mathrm{p}$-value $<0.05$ ).

Based on the results of hypothesis testing, showed that the process of procurement and distribution of drugs have a relationship with a pharmacist satisfaction. In addition, the pharmacy services such as drug availability, service time, and the provision of drug information have a relationship with the satisfaction of patients.

\section{The relationship between JKN and phar macist satisfaction}

Inaccessibility of drugs in health facilities by the public occurs because health facilities have a list of different drugs so that the government make a list of essential drugs should be available at every health facility in the generic name of this drug and the list updated every two years (Roy, 2013). The availability and affordability of essential medicines by patients is important in ensuring the success of health system (Ahmed and Islam, 2012). Pharmacists responsible for ensuring the availability of drugs to procure drugs using ecatalog as well as the refers back program. This may increase the workload of pharmacists that affect pharmacists satisfaction, indicated with $\mathrm{p}$ $=0.010$ (Buciuniene et al., 2005).

Procurement of drugs in the health centers is done through health districts/cities and Pharmacy Warehouse District/City by filing LPLPO (Report Drug Use And Sheets Demand) so that the procurement of the ecatalog will be conducted by Pharmacy Warehouse District/City (Al-Hijrah et al., 2013). Procurement of drugs by Pharmacy Warehouse District/City should ensure the availability of drugs to health centers in the region overall. The use of e-catalog for procurement are still many an obstacle for pharmacists in health centers due to prolong the procurement process and there are some goods medical consumables have less good quality than is normally used. 
Tabel I. Interpretation variables in questionnaire

\begin{tabular}{lll}
\hline \multicolumn{1}{c}{ Variable } & \multicolumn{1}{c}{ Number of Questionnaire } & \multicolumn{1}{c}{ Description } \\
\hline Drug procurement process & $1,2,4,7,10$ & \\
Drug distribution process & $3,5,6,9,15,16,18$ & Questionnaire for pharmacist \\
Drug costs claiming process & $8,11,12,13,14,17$ & \\
Pharmacist satisfaction & $19,20,21,22,23,24,25,26$ & \\
Drug availability & $1,2,3,4,5,6$ & \\
Drug information services & $14,15,16,17,18,19,20,21,22$ & Questionnaire for patient \\
Service time & $7,8,9,10,11,12,13,23$ & \\
Patient satisfaction & $24,25,26,27,28,29,30,31,32$ & \\
\hline
\end{tabular}

Tabel II. Patient characteristics

\begin{tabular}{|c|c|c|c|}
\hline \multirow{2}{*}{ Characteristics } & \multirow{2}{*}{ Parameter } & \multicolumn{2}{|c|}{ Quantity of Participants $(n=150)$} \\
\hline & & $\mathbf{N}$ & $\%$ \\
\hline \multirow{4}{*}{ Age } & $18-32$ years & 34 & 22.67 \\
\hline & $33-47$ years & 52 & 34.67 \\
\hline & $48-62$ years & 34 & 22.67 \\
\hline & $>62$ years & 30 & 20.00 \\
\hline \multirow{3}{*}{ Gender } & Male & 39 & 26.00 \\
\hline & Female & 111 & 74.00 \\
\hline & Elementary school & 21 & 14.00 \\
\hline \multirow{4}{*}{ Education } & Pre elementary school & 25 & 16.67 \\
\hline & High school & 42 & 28.00 \\
\hline & Diploma/graduate & 37 & 24.67 \\
\hline & Post graduate & 25 & 16.67 \\
\hline \multirow{6}{*}{ Occupation } & Entrepreneur & 34 & 22.67 \\
\hline & Civil servant & 26 & 17.33 \\
\hline & Retired & 3 & 2.00 \\
\hline & Private employees & 10 & 6.67 \\
\hline & Others & 77 & 51.33 \\
\hline & $<1$ million rupiah & 92 & 61.33 \\
\hline \multirow{5}{*}{ Income } & 1-2 million rupiah & 39 & 26 \\
\hline & 2-3 million rupiah & 14 & 9.33 \\
\hline & 3-4 million rupiah & 4 & 2.67 \\
\hline & $>4$ million rupiah & 1 & 0.67 \\
\hline & Beneficiaries dues & 90 & 60.00 \\
\hline \multirow{2}{*}{$\begin{array}{l}\text { Membership } \\
\text { status }\end{array}$} & Worker wage earners & 39 & 26.00 \\
\hline & Worker not wage earners & 21 & 14.00 \\
\hline
\end{tabular}

In this study, obtained results which indicate that the drug distribution process have a relationship with a pharmacist satisfaction (sig 0.002). Procurement of drugs in the health centers is done collectively through pharmaceutical warehouse so the warehouse pharmacy is responsible for distributing medicines in health centers across the region in scope. WHO estimates that approximately 1.3 to 2.1 million people in the world, especially the low-income and middle still not getting access to essential drugs. Factors affecting access to drugs among other drugs cost, availability, proper storage, distribution, and use of drugs rationally (Roy, 2013). With the pattern of spread of the Indonesian population is scattered, it is necessary efficiency and effectiveness of the distribution system to support the availability, affordability and sustainable drug equalization (Bina Kefarmasian dan Alat Kesehatan, 2006). 
Tabel III. Relationship analysis of patient characteristics with patient satisfaction

\begin{tabular}{|c|c|c|}
\hline Relationship & $\mathrm{p}$ & Result \\
\hline Age with patient satisfaction & 0.000 & $\begin{array}{l}\text { there is a significant relationship between age and patient } \\
\text { satisfaction }\end{array}$ \\
\hline $\begin{array}{l}\text { Gender with patient } \\
\text { satisfaction }\end{array}$ & 0.039 & $\begin{array}{l}\text { there is a significant relationship between gender and } \\
\text { patient satisfaction }\end{array}$ \\
\hline $\begin{array}{l}\text { employment with patient } \\
\text { satisfaction }\end{array}$ & 0.444 & $\begin{array}{l}\text { there is no a significant relationship between employment } \\
\text { and patient satisfaction }\end{array}$ \\
\hline $\begin{array}{l}\text { education with patient } \\
\text { satisfaction }\end{array}$ & 0.212 & $\begin{array}{l}\text { there is no a significant relationship between education } \\
\text { and patient satisfaction }\end{array}$ \\
\hline $\begin{array}{l}\text { Income with patient } \\
\text { satisfaction }\end{array}$ & 0.000 & $\begin{array}{l}\text { there is a significant relationship between income and } \\
\text { patient satisfaction }\end{array}$ \\
\hline $\begin{array}{l}\text { Membership status with } \\
\text { patient satisfaction }\end{array}$ & 0.389 & $\begin{array}{l}\text { there is no a significant relationship between membership } \\
\text { status and patient satisfaction }\end{array}$ \\
\hline
\end{tabular}

Tabel IV. Factors affecting satisfaction

\begin{tabular}{|c|c|c|c|}
\hline $\begin{array}{c}\text { Dependent } \\
\text { Variabel }\end{array}$ & $\begin{array}{c}\text { Independent } \\
\text { Variabel } \\
\end{array}$ & $\mathrm{p}$ & Result \\
\hline \multirow{3}{*}{$\begin{array}{l}\text { Pharmacist } \\
\text { Satisfaction }\end{array}$} & $\begin{array}{l}\text { Drug procurement } \\
\text { process }\end{array}$ & 0.010 & $\begin{array}{l}\text { There is a relationship between the drug } \\
\text { procurement process to the patient satisfaction }\end{array}$ \\
\hline & $\begin{array}{l}\text { Drug distribution } \\
\text { process }\end{array}$ & 0.002 & $\begin{array}{l}\text { There is a relationship between the drug } \\
\text { distribution process to the patient satisfaction }\end{array}$ \\
\hline & $\begin{array}{l}\text { Drug costs } \\
\text { claiming process }\end{array}$ & 0.261 & $\begin{array}{l}\text { There is no a relationship between the drug costs } \\
\text { claiming process to the patient satisfaction }\end{array}$ \\
\hline \multirow{3}{*}{$\begin{array}{l}\text { Patient } \\
\text { Satisfaction }\end{array}$} & Drug availability & 0.003 & $\begin{array}{l}\text { There is a relationship between the drug } \\
\text { availability to the patient satisfaction }\end{array}$ \\
\hline & Service time & 0.006 & $\begin{array}{l}\text { There is a relationship between the service time to } \\
\text { the patient satisfaction }\end{array}$ \\
\hline & $\begin{array}{l}\text { Drug information } \\
\text { service }\end{array}$ & 0.000 & $\begin{array}{l}\text { There is a relationship between the drug } \\
\text { information service to the patient satisfaction }\end{array}$ \\
\hline
\end{tabular}

Refer back program in JKN era has several rules and policies that must be understood that there is an imbalance pharmacist workforce and workload that can affect satisfaction of the pharmacist (Ferdinandus, 2014). From Table 4 it is known that the drug claim costs not related to the satisfaction of the pharmacist (sig 0.261). Some factors that affect this include pharmacists in the health center does not deal with the problem of drug claim costs for directly handled by the administration and during the ongoing JKN system pharmacist in health center has not run the program. Socialization of BPJS Kesehatan to health center pharmacist about the program conducted in October 2014. Another obstacle is the lack of coordination between BPJS Kesehatan, drug distributors, and health care providers. Required cooperation between specialists, primary care physicians, and pharmacists in managing chronic diseases as well as good recording system is needed so that health teams can interact (Cassel, 2012). 
Table V. Results of multiple linear regression analysis

\begin{tabular}{clccc}
\hline Dependent Variabel & \multicolumn{1}{c}{ Independent Variabel } & $\mathbf{p}$ & $\mathbf{R}$ & $\mathbf{R}^{2}$ \\
\hline \multirow{2}{*}{ Pharmacist Satisfaction } & $\begin{array}{l}\text { Drug procurement process } \\
\text { Drug distribution process } \\
\text { Drug costs claiming process }\end{array}$ & 0,011 & 0,514 & 0,265 \\
& & & \\
\hline
\end{tabular}

Table VI. Results of multiple linear regression drug availability, service time, and drug information service with patient satisfaction

\begin{tabular}{|c|c|c|c|}
\hline Dependent Variabel & Independent Variabel & $\mathbf{P}$ & Result \\
\hline \multirow{3}{*}{ Patient Satisfaction } & Drug availability & \multirow{3}{*}{0.000} & There is a relationship between the \\
\hline & Service time & & drug availability, service time, and \\
\hline & $\begin{array}{l}\text { Drug information } \\
\text { service }\end{array}$ & & $\begin{array}{l}\text { drug information service to the } \\
\text { patient satisfaction }\end{array}$ \\
\hline
\end{tabular}

\section{The relationship between drug availability and patient satisfaction}

Public access to the drug is strongly influenced by the availability of drugs. The availability of complete cure will be easier for people to search for the required drug needs. Supply of drugs tailored to the needs of the community and the non-current inventory of drugs will hinder health service. This is because the drug is not available when needed so as to affect the loyalty of patients. Completeness drug had positive effect on patient visits (Trimurthy, 2009). The analysis showed the value of $p=0.003(p<0.05)$ so that there was a significant correlation between the availability of drugs to JKN patients satisfaction in Primary Heath Facilities.

According to the results of the interview to the respondents, most patients were satisfied with the availability of drugs in primary clinics and health centers, but there were obstacles such as limited of drug especially the availability of drugs. Patients were only given medication for 7-10 days so the patient must return to the primary health facilities to take drugs once more. However, this did not significantly influence patient satisfaction.

The necessary coordination of all parties to the National Health Insurance system could make the program running well. On the issue of the availability, government make the national drug formulary with e-catalog system to ensure the affordability and availability of medicines. Pharmacists who are in health care facilities are expected to conduct effective and efficient procurement so there is no vacancy in drug availability. Distribution of drugs to health centers also affect the availability of drugs, therefore, the Pharmacy Warehouse District/ City also have to make a schedule of drug distribution to each unit of health care in order to ensure continuous availability of drugs. The cooperation of all parties will be able to provide maximum service to patients.

\section{The relationship between service time and patient satisfaction}

Personnel speed in providing services according to the waiting time is 25 minutes for services compounded prescription and 15 minutes for prescription without concoction (Harijono and Soepangkat, 2011). Research conducted by Kurniawan (2012) showed that the speed of service influence on patient satisfaction. Widiyawati (2011) also stated that the speed of service had a positive effect on customer loyalty. 
Results of analysis to the relationship between service time and patient satisfaction was $p=0.006(p<0.05)$, which means there is a significant correlation between the time of service with the satisfaction of JKN patients. The service time was affected by the number of visiting patient. If there were a lot of visiting patients and most of them got compounding prescriptions, eventually making the service relatively slow.

For administrative process flow starting from taking a queue number to adjustment data themselves, did not take a long time. For taking compounded prescription or prescription without concoction, checking drugs and drugs delivery also did not require a long time Personnel speed in providing services to patients did not significantly affect patient satisfaction because of services in primary clinics and health centers relatively fast.

Pharmacy services at health centers conducted by Pharmacists or Pharmacist Assistant. Not all health centers have pharmacists, but there are also health centers have only pharmacists without Pharmacist Assistant. It can be seen that the timing of drug services to patients was highly dependent on the number of pharmacy personnel. With the $\mathrm{JKN}$, the number of patients in each health center were increase but the number of pharmacy personnel remained the same. In addition, pharmacist also must perform the pharmaceutical administration and conduct of procurement and create some reports related to drugs. This will affect the timing of drug services to patients.

\section{The relationship between drug information service and patient satisfaction}

Drug information services is a supply and provision of drug information and accurate recommendations by the pharmacist to the patient (Trimurthy, 2009). Results of statistical analysis showed $\mathrm{p}=0.000(\mathrm{p}<0.05)$, which means there was a significant relationship between the provision of drug information with $\mathrm{JKN}$ patient satisfaction.

According to the results of interviews to some respondents, the information provided by the pharmacy attendant were easily understood, such as how to use, time of use, duration of use, and storage of drugs. Other information such as drug interactions are still rarely given. Drug information given in limited centers with a very short time due to the number of patients and the lack of human resources. Some health centers also did not have pharmacists who should be responsible for providing information when giving medicine to a patient even though drug information greatly affect the success of treatment of patients.

\section{Multiple linear regression analysis}

Multiple linear regression analysis was conducted to see the effect of several simultaneous independent variables on the dependent variable.

Multiple correlation analysis was used to determine the relationship of two or more independent variables on the dependent variables simultaneously. The correlation coefficient $(\mathrm{R})$ was 0.514 where according to criteria in Dahlan (2011) the value of the correlation coefficient from 0.40 to 0.599 have a medium level of closeness. Test of determination $\left(R^{2}\right)$ was 0.265 where this value indicated that the process of drug procurement and distribution processes of drug effect on satisfaction of pharmacist by $26.5 \%$ and the remaining $73.5 \%$ was influenced by other variables outside the model. $\mathrm{F}$ test showed $\mathrm{p}=$ $0.011(<0.05)$ concluded that there was a significant relationship between the process of drug procurement and distribution process to the pharmacist satisfaction, simultaneously.

In order to suffice in drugs, the government implemented the concept of the use of essential medicines by generic name as well as the procurement using the system enforces quality assurance and central procurement. By performing centralized procurement, the drug will be obtained cheaper and improved the ease and ability to deliver medication to the patient. The government also made a committee of procurement and distribution of drugs to ensure the availability and affordability of essential medicines in public health facilities (Roy, 2013). The existence of rules, policies, and procedures that must be followed as well as several documents related to the drugs procurement and 
distribution systems in the JKN era migth increase the workload of pharmacists so as to affect the satisfaction of pharmacists (Buciuniene et al., 2005). Results of linear regression $\mathrm{p}=0.000$ showed that the three independent variables simultaneously affected the patient satisfaction. This was due to the three inter-related variables that would affect each other.

\section{CONCLUSION}

The conclusion of this study was the process of procurement and distribution of drugs have a relationship with a pharmacist satisfaction. In addition, the availability of pharmacy services such as medication, a drug services, and the provision of drug information also had a significant relationship to the satisfaction of outpatients in primary health facilities.

\section{REFERENCES}

Ahmed SM., Islam QS., 2012. Availability and Rational Use Of Drugs In Primary Healthcare Facilities Following The National Drug Policy Of 1982: Is Bangladesh On Right Track? J. Health, Population, and Nut, 30: 99108.

Anjaryani WD., 2009, Kepuasan Pasien Rawat Inap Terhadap Pelayanan Perawat Di RSUD Tugurejo Semarang, Universitas Diponegoro, Semarang

Aziri B., 2011. Job Satisfaction: A Literature Review. Man. Res. Prac., 3: 77-86.

Bina Kefarmasian Dan Alat Kesehatan, 2006. Kebijakan Obat Nasional. Jakarta.

Buciuniene I., Blazeviciene, A., Dan Bliudziute, E., 2005. Health Care Reform And Job Satisfaction Of Primary Health Care Physicians In Lithuania. BMC Family Practice, .

Cassel CK., 2012. Retail Clinics And Drugstore Medicine. JAMA, 307: 2151-2152.

Dahlan MS., 2011. Satistik Untuk Kedokteran Dan Kesehatan, Edisi 5. Ed. Salemba Medika, Jakarta.

Departemen Kesehatan, 2004. Undang-Undang Republik Indonesia Nomor 40 Tabun 2004 Tentang Sistem Jaminan Sosial Nasional.
Kementrian Kesehatan Republik Indonesia, Jakarta.

Departemen Kesehatan, 2011. Undang-Undang Republik Indonesia Nomor 24 Tabun 2011 Tentang Badan Penyelenggara Jaminan Sosial. Kementrian Kesehatan Republik Indonesia, Jakarta.

Ferdinandus ME., 2014. Pemberdayaan Puskesmas Menur Dalam Rangka Peningkatan Kualitas Pelayanan Publik Bidang Kesehatan 2: .

Harijono H., Soepangkat BO. 2011. Upaya Peningkatan Kualitas Layanan Farmasi RSK. ST VINCENTIUS A PAULO Surabaya Dengan Menggunakan Metode Servqual Dan QFD. Prosiding Seminar Nasional Manajemen Teknologi XIV Program Studi MMT-ITS, Surabaya 23 Juli 2011

Kementrian Kesehatan, 2013. Peraturan Menteri Kesehatan Republik Indonesia Nomor 71 Tabun 2013 Tentang Pelayanan Kesehatan Pada Jamin Kesehatan Nasional. Kementrian Kesehatan Republik Indonesia, Jakarta.

Kurniawan F. 2012. Kecepatan Waktu Pelayanan Rumah Sakit Berpengarub Terhadap Kepuasan Pasien, URL: http:/ / stikesbaptis.ac.id/ utama.

Muliawan BT., 2013. Implementasi Program Prioritas DIT Bina Obat Publik Dan Perbekes Tabun 2013. Dipresentasikan di Yogyakarta 2013

Notoatmodjo S., 2010. Ilmu Perilaku Kesehatan. Rineka Cipta, Jakarta.

Pohan IS., 2007. Jaminan Mutu Pelayanan Kesehatan Dasar-Dasar Pengertian Dan Penerapan. Penerbit Buku Kedokteran EGC.

Ratnasari C., 2012, Hubungan Ketersediaan Fasilitas, Keramahan, Lama Pelayanan, Usia Dan Tingkat Pendidikan Terhadap Pemiliban Tempat Pemberi Pelayanan Kesehatan Pada Peserta Askes (Studi Kasus Di Wilayah KerjaPuskesmasPandanaran Kota Semarang), Universitas Diponegoro, Semarang

Roy V., 2013. A Way To Low Cost, Quality Medicines: Implementation of An Essential Medicines Policy In Public Health Facilities In Delhi (India). 
Satibi

Trimurthy I. 2009. Analisis Hubungan Persepsi Pasien Tentang Mutu Pelayanan Dengan Minat Pemanfaatan Ulang Pelayanan Rawat Jalan Puskesmas Pandanaran Kota Semarang. (Tesis). Semarang. Universitas Diponegoro.
Widiyawati N. 2011. Pengaruh Kualitas Layanan Terhadap Loyalitas Pelanggan Di Supermarket Papaya Darmo Surabaya. Jurnal Akutansi, Manajemen Bisnis, Dan Sektor Publik (JAMBSP). Surabaya 